\title{
Species diversity and regeneration status of community-managed hill sal (Shorea robusta) forest in Central Nepal
}

\author{
Krishna Prasad Sharma ${ }^{1,3}$, Suresh Prashad Bhatta ${ }^{2, *}$ and \\ Santosh Kumar Lamsal ${ }^{1}$ \\ ${ }^{1}$ Department of Botany, Amrit Campus, Tribhuvan University, Kathmandu 44600, Nepal \\ ${ }^{2}$ Central Department of Botany, Tribhuvan University, Kirtipur, Kathmandu 44613, Nepal \\ ${ }^{3}$ Budhanilkantha School, Kathmandu 44622, Nepal
}

This study assessed the species composition, community structure and regeneration status of hill sal forest of Baglung district, Central Nepal after about two decades of community management. We also compared the species composition, community structure and regeneration status of two sites of the forest having different disturbance intensities prior to management. The purposive sampling method was applied for data collection, where we divided the community forest into five vertical transects and in each transect six $20 \mathrm{~m} \times 20 \mathrm{~m}$ plots were established. All tree and shrub species were recorded for each sample plot and their height and diameter at breast height (for tree) or basal circumference area (for shrub) were measured. The nested quadrat method was used for assessing the regeneration status at three life stages, viz. seedlings, saplings and trees. Twenty-seven species belonging to 21 families were recorded, where sal was the dominant species and Dipterocarpaceae was the dominant family. Size-class distribution curve showed that the studied forest was not sustainable and viable but regeneration count depicted that it had good regeneration status with a sufficient number of seedlings and saplings to replace the adults after their mortality. Similarly, the number of species, as well as the density of seedlings, saplings and trees, were found higher in the disturbed site than in the relatively undisturbed site of the forest. Thus, our study indicated that there are considerable differences between the disturbed site and relatively undisturbed site prior to management in terms of diversity, species composition, stand structure and regeneration pattern.

Keywords: Diversity disturbance, importance value index, seedling count, similarity indices, species richness.

A plant community is a composition of plant species growing together in a particular location with a definite association with each other ${ }^{1}$. The community composition and structure of a forest tree are important in understand-

*For correspondence. (e-mail: sureshbhatta2@gmail.com) ing the status of tree population, regeneration and diversity for planning, management and conservation activities ${ }^{2,3}$. Applying phytosociological analysis as the quantitative method is important for the assessment of community composition and structure. However, assessment of tree communities is usually site-specific and largely depends on various ecological characteristics of sites such as composition, abundance, distribution, dominance, diversity and regeneration status of species which help determine the natural regeneration processes and dynamics ${ }^{4,5}$. The structure and diversity of the forest ecosystem are influenced by topography, soil, climate, geographical location of a region ${ }^{6}$, changes in overstorey structure like species distribution and canopy cover ${ }^{7}$, and composition ${ }^{8}$ of natural regeneration of some species.

Plant regeneration is the process of forming new individuals by means of sexual, asexual or any other kind of reproductive mechanism to maintain and expand the population in a community with time and space ${ }^{9}$. Regeneration is measured to determine whether it meets the objectives of sustainable forest management, in particular, whether the productive capacity and biological diversity of the forest are maintained and preserved ${ }^{10}$. The potential regenerative status of tree species demonstrates a development trend of the community, species composition and stability of the forests in the future ${ }^{11,12}$. Similarly, regeneration status of a forest indicates its health and vitality; a healthy and sustainable forest must have good regeneration, proper age class, normal increment and normal growing stock $^{13}$. Age-class analysis of different tree species is the commonly used method for reproductive and regeneration analysis of a forest ${ }^{14,15}$. The number of individuals at different age classes (density-diameter curve), when plotted as a graph, can give the basic trends of regeneration of viability of the community. If the forest has a large number of big trees and a low number of small trees, then the plot will be $J$-shaped, which is an ecologically unstable community because it does not have the population to replace the older trees after their death or any other disasters. But if the forest has a large number of small-aged trees and also a sufficient population in 
higher age classes, then the plot will be inverse $J$-shaped, which is considered as an ecologically stable or viable community $^{14}$. Species having a sufficient number of seedlings and saplings are considered to have poor regeneration, while those with an inadequate number of seedlings and saplings are considered to a have poor regeneration, while complete absence of seedlings and saplings of tree species in a forest indicates no regeneration ${ }^{5,15,16}$.

Plant regeneration mainly depends upon the ability to initiate new seedlings, ability of the seedlings and saplings to survive, grow and establishment, and also on the average seed output, viability of seeds, seed dormancy, seed dispersal, vegetative growth and reproductive growth ${ }^{11,17}$. Regeneration of tree species and the survival and growth of their seedlings is affected directly or indirectly by various abiotic and biotic factors of the forest environment ${ }^{18,19}$. Plants could generally grow and survive in a limited range of environmental gradients such as temperature $^{20}$, light availability ${ }^{20}$ and precipitation ${ }^{21}$. Variations in these factors play an important role in shaping the age structure and forest regeneration at different altitudes $^{22}$. Several types of disturbances like logging, landslides, gap formation, litterfall, herbivory, etc. can affect the potential regenerative status of species in the forest stand, both spatially and temporally ${ }^{5}$.

Community forestry programme is the most successful management practice in Nepal, which was formally launched in 1978 (ref. 23). Till date, 1,813,478 ha of national forest has been handed to 19,361 community forestry users' groups (CFUGs) in $\mathrm{Nepal}^{24}$. The community forestry programme has two important roles; the first is conservation of biodiversity and other ecosystem services, and the second is livelihood and capacity development of local people through sustainable use of forest resources. Whether or not the community forestry programme has conserved biodiversity and greenery in Nepal, the recent concern is whether the management practices are ecologically sustainable or not. Selection thinning, selective cutting, floor clearance, dead-log removals, etc. are some ecological problems of community forestry ${ }^{25}$. The other problems of sal forests are borer attack, mortality, poor regeneration potential, edaphoclimatic changes and various biotic interferences ${ }^{26}$. Dieback is common in individuals of lower sizes and seems to be an inherent property of the species, enabling it to survive under unfavourable conditions such as winter frost and moisture deficiency. In sal, the time interval between two good seed crops is 2-4 years, and synchronization of a good seed crop with the timely arrival of monsoon may occur once in 25-30 years ${ }^{19}$. Thus, temperature and moisture regimes of the surface soil are also the causes of mortality of sal seedlings.

In the present study, we analyse the species composition, community structure and regeneration status of sal-dominated community forest (CF) of Baglung district, Central Nepal after about two decades of management.
Further, the density, species composition and regeneration status of two sites of the forest having different disturbance intensities prior to management were also analysed and compared. This study will provide baseline data for understanding the impacts of disturbance on forest composition and regeneration, formulation of conservation and management strategies, long-term monitoring processes and also to assess the different ecological consequences of the present and future on the forest ecosystem.

\section{Materials and methods}

\section{Study area}

The study was conducted in Pallo Pakha CF of Jaimini municipality-01, Kushmisera, Baglung district, western Nepal, located between $83^{\circ} 37^{\prime} 35^{\prime \prime}-83^{\circ} 37^{\prime} 41^{\prime \prime} \mathrm{E}$ and $28^{\circ} 11^{\prime} 10^{\prime \prime}-28^{\circ} 11^{\prime} 21^{\prime \prime} \mathrm{N}$, with an altitude ranging from 850 to $1150 \mathrm{~m}$ asl (Figure 1). It was managed as a CF after 2054 BS (Bikram Sambat; AD 1997). Phyto-geographically it is in the subtropical zone. The aspect of the slope is southeast, which receives sunlight for the full day sun radiation. Due to the rocky slope soil depth is thin in most parts, not exceeding $30 \mathrm{~cm}$. The forest area is about 10 ha and dominated with sal and associated species like Schima wallichii (DC) Korth and Diospyros lancifolia Roxb. The forest experienced a different level of disturbance prior to community management. The lower part of the forest was subjected to high disturbance and the upper part of the forest was relatively undisturbed prior to management. After community management, only silvicultural practices were carried out on a rotational basis depending upon the number of blocks in the $\mathrm{CF}$ - basically once in 3-4 years in a block - while other human activities were strictly prohibited in the $\mathrm{CF}$, except seasonal fodder and firewood collection.

\section{Sampling methodology}

Vegetation sampling data were collected in October 2016. The purposive sampling method was applied for data collection. The whole CF was divided into two parts based on the disturbance intensity prior to management. The lower part of the forest which was subjected to high disturbance was referred to as the first site (hereafter site A) and the upper part which was relatively undisturbed prior to management was referred to as the second site (hereafter site B). When assessing the past disturbances, only harvesting activities (tree felling) were considered ${ }^{27}$. This was done by observing the density and basal area of the remaining mature trees. Grazing, litter collection, selective cutting, soil disturbances, selective thinning and fodder collection were considered as the present disturbances. 


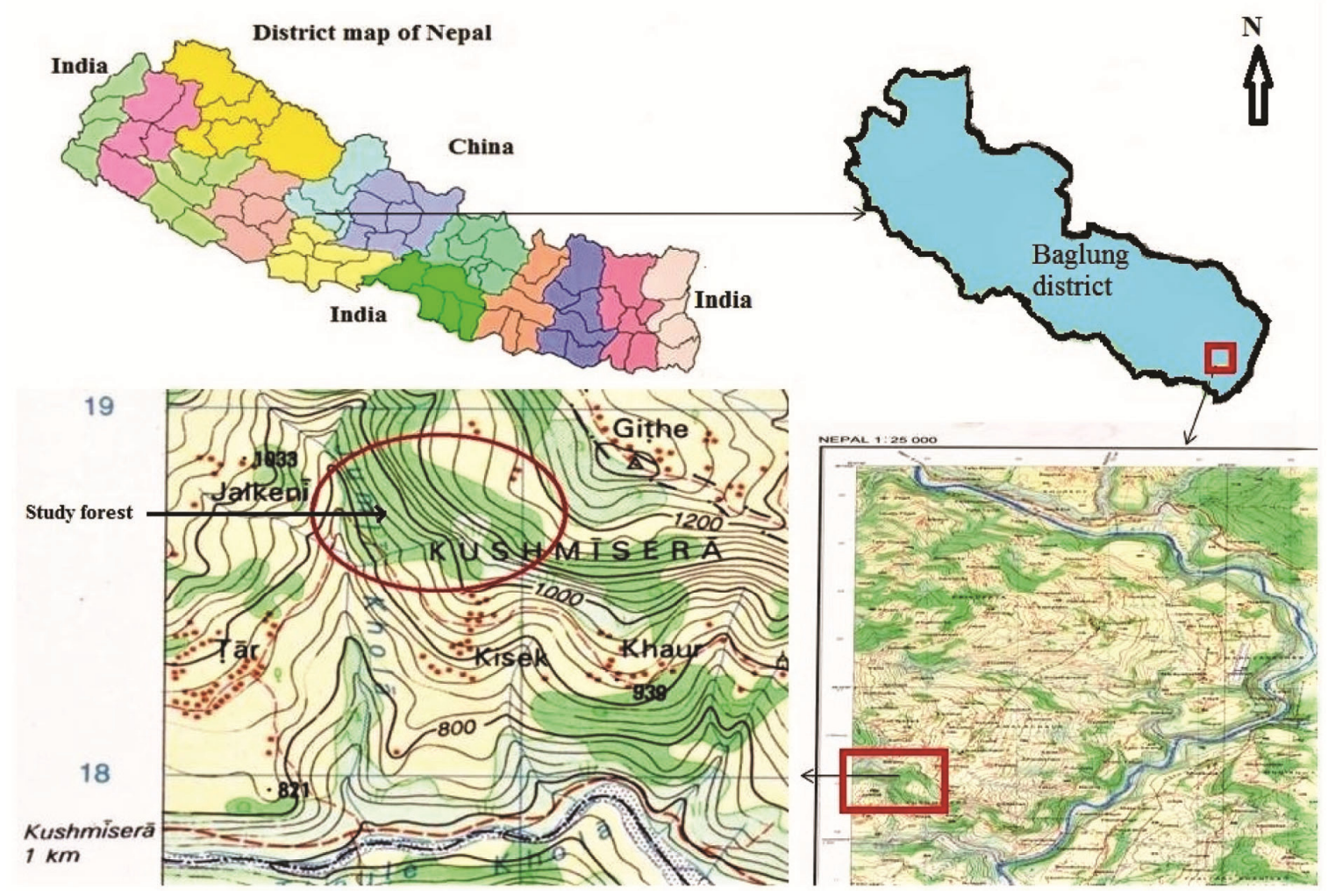

Figure 1. Map of Nepal showing the location of the study area.

The CF was divided into five vertical transects separated by a distance of $100 \mathrm{~m}$. In each transect, six $20 \mathrm{~m} \times 20 \mathrm{~m}$ plots were established and the distance between each plot was at least $50 \mathrm{~m}$. Altogether 30 plots $(6 \times 5=30)$ were studied, 15 plots $(3 \times 5=15)$ in site $\mathrm{A}$ and 15 plots $(3 \times 5=15)$ in site B. All tree and shrub species were recorded for each sample plot. Diameter at breast height (DBH, $137 \mathrm{~cm})$ was measured for each tree species using DBH tape and the height $(H>137 \mathrm{~cm})$ of small trees $(<8 \mathrm{~m})$ was estimated using a reference stick of $4 \mathrm{~m}$, while the height of large trees $(>8 \mathrm{~m})$ was estimated by a clinometer. The basal circumference of each stem of shrub species was measured at $15 \mathrm{~cm}$ above the ground surface ${ }^{28}$. The nested quadrat method was used for regeneration count, where saplings were counted in $5 \mathrm{~m} \times 5 \mathrm{~m}$ plots and seedlings in $1 \mathrm{~m} \times 1 \mathrm{~m}$ plots $^{29,30}$. Regeneration status of forests was assessed at three life stages, viz. seedlings $(<137 \mathrm{~cm}$ height $)$, saplings $(<5 \mathrm{~cm}$ DBH and $>137 \mathrm{~cm}$ height $)$ and trees $(\geq 5 \mathrm{~cm} \mathrm{DBH})^{31}$. The plots having slope $>45^{\circ}$ were avoided and sampling was done in the adjacent area. The geographic location and slope of each plot were recorded using a global positioning system (GPS) and clinometer from the centre of the plot respectively.

The plant specimens were identified with the help of standard literatures ${ }^{32,33}$ and by consulting experts. Annotated Checklist of the Flowering Plants of Nepal was used for nomenclature of specimens ${ }^{34}$.

\section{Data analysis}

The data were analysed to calculate the frequency, density, basal area, relative values of frequency, density, basal area and importance value index (IVI) of only the plants having DBH $\geq 5 \mathrm{~cm}$, following the previously described standard method ${ }^{35}$. To assess the regeneration status of the forest, the density of seedlings, saplings and trees was determined separately following the standard method described previously ${ }^{35}$. The total number of plants of all species recorded in all $20 \mathrm{~m} \times 20 \mathrm{~m}$ quadrats was divided into different size classes based on DBH of $5 \mathrm{~cm}$ interval. Then, size class-diagrams of the entire study area and two study sites, as well as of dominant tree species, i.e. sal in the entire forest and two study sites were prepared to analyse the structural composition. The species richness was calculated as the number of species present per sample $\operatorname{plot}^{36}$. Jaccard and Sorensen similarity indices were also calculated $^{37}$. Species-area curves were drawn from the total number of plant species found in different sample plots.

Descriptive statistics was applied to generate means for the comparison study. The mean values of species richness were compared between two sites of the forest (sites $\mathrm{A}$ and B) using $t$-test. Prior to this, data were tested for normality (Shapiro-Wilk test, $P>0.05$ ). All the analyses were done using Microsoft Excel 2007 (Microsoft Corp, WA, USA) and Statistical Package for Social Sciences (SPSS) version 20 (IBM Corp., NY, USA). 
Table 1. Species recorded in the study area and two different sites (A and B) of the study area according to disturbance level prior to management

\begin{tabular}{|c|c|c|c|c|}
\hline Family & Species & Life form & $\begin{array}{l}\text { Species in } \\
\text { site A }\end{array}$ & $\begin{array}{l}\text { Species } \\
\text { in site } B\end{array}$ \\
\hline \multirow[t]{2}{*}{ Anacardiaceae } & Mangifera indica & $\mathrm{T}$ & + & - \\
\hline & Rhus javanica & $\mathrm{T}$ & + & - \\
\hline Betulaceae & Alnus nepalensis & $\mathrm{T}$ & + & - \\
\hline Bombacaceae & Bombax ceiba & $\mathrm{T}$ & + & - \\
\hline Combretaceae & Terminalia alata & $\mathrm{T}$ & - & + \\
\hline Dipterocarpaceae & Shorea robusta & $\mathrm{T}$ & + & + \\
\hline Ebenaceae & Diospyros lancifolia & $\mathrm{T}$ & + & + \\
\hline Ericaceae & Lyonia ovalifolia & $\mathrm{T}$ & + & + \\
\hline \multirow[t]{2}{*}{ Euphorbiaceae } & Mallotus philippensis & $\mathrm{T}$ & + & - \\
\hline & Phyllanthus emblica & $\mathrm{T}$ & - & + \\
\hline \multirow[t]{3}{*}{ Fabaceae } & Dalbergia sissoo & $\mathrm{T}$ & + & - \\
\hline & Bauhinia vahlii & $\mathrm{S}$ & + & + \\
\hline & Bauhinia purpurea & $\mathrm{T}$ & + & - \\
\hline Fagaceae & Castanopsis indica & $\mathrm{T}$ & + & - \\
\hline Lauraceae & Litsea monopetala & $\mathrm{T}$ & - & + \\
\hline Lythraceae & Woodfordia fruticosa & $\mathrm{S}$ & + & - \\
\hline Meliaceae & Toona ciliata & $\mathrm{T}$ & + & - \\
\hline \multirow[t]{3}{*}{ Moraceae } & Ficus benjamina & $\mathrm{T}$ & + & - \\
\hline & Ficus lacor & $\mathrm{T}$ & - & + \\
\hline & Ficus semicordata & $\mathrm{T}$ & - & + \\
\hline Myrtaceae & Syzygium cumini & $\mathrm{T}$ & + & - \\
\hline Oleaceae & Fraxinus floribunda & $\mathrm{T}$ & + & + \\
\hline Pinaceae & Pinus roxburghii & $\mathrm{T}$ & + & - \\
\hline Rosaceae & Pyrus pashia & $\mathrm{T}$ & + & + \\
\hline Sapotaceae & Aesandra butryracea & $\mathrm{T}$ & - & + \\
\hline Theaceae & Schima wallichii & $\mathrm{T}$ & + & + \\
\hline Ulmaceae & Celtis australis & $\mathrm{T}$ & + & - \\
\hline
\end{tabular}

Site A, Disturbed site prior to community management; Site B, Relatively undisturbed site prior to community management; T, Tree; S, Shrub; +, Presence; -, Absence.

Table 2. Species richness $(S)$ of the two studied sites (A and B), and Jaccard $(J)$ and Sorensen $(L)$ similarity indices of the study area

\begin{tabular}{|c|c|c|c|c|c|c|}
\hline Variables & $\begin{array}{c}\text { Site A } \\
(\text { mean } \pm S E)\end{array}$ & $\begin{array}{c}\text { Site B } \\
(\text { mean } \pm S E)\end{array}$ & $\mathrm{d} f$ & $t$ & $P$ & Entire study area \\
\hline Species richness & $5 \pm 0.32$ & $2.73 \pm 0.32$ & 28 & 5.013 & $0.000 *$ & - \\
\hline Jaccard index & - & - & - & - & - & 0.259 \\
\hline Sorensen index & - & - & - & - & - & 0.412 \\
\hline
\end{tabular}

SE, Standard error; $\mathrm{d} f$, Degree of freedom; $t$, Value obtained from $t$-test; $P$, Significance level; *Indicates significant difference.

\section{Results}

\section{Forest structure, composition and taxonomic} diversity

Altogether, 27 plant species belonging to 24 genera and 21 families were recorded in the study area (Table 1). Among these, 25 were tree species belonging to 23 genera and 20 families, while only two shrub species belonging to two genera and two families were recorded in the study area. Similarly, in site A, 21 plant species belonging to 20 genera and 18 families were recorded, while in site B, 13 plant species belonging to 13 genera and 12 families were recorded (Table 1). Fabaceae and Moraceae consisted of three species, while most others were mono-species families (Table 1). The species richness of site A $(5 \pm 0.32)$ was higher than that of site B $(2.73 \pm 0.32$; Table 2). Similarly, Jaccard and Sorensen similarity indices of the study area were 0.259 and 0.412 respectively (Table 2).

Species-area curve indicated that the species were present in all the sampled plots in both sites. The species present in the sample plots in both sites were on the discontinuous pattern, i.e. increasing and decreasing pattern was observed (Figure 2). The number of species per plot was higher in site A than in site B. 
Table 3. Frequency $(F)$, relative frequency $(\mathrm{RF})$, density $(D)$, relative density (RD), basal area (BA), relative basal area (RBA) and importance value index (IVI) of plant species in site A of the study area

\begin{tabular}{lccccccc}
\hline Species & $F(\%)$ & RF $(\%)$ & $D\left(\right.$ plants ha $\left.{ }^{-1}\right)$ & RD (\%) & BA (\%) & RBA (\%) & IVI \\
\hline Shorea robusta & 100 & 22.39 & 804 & 70.00 & 13.32 & 29.77 & 122.17 \\
Schima wallichii & 60 & 13.44 & 100 & 8.71 & 4.41 & 9.86 & 32.00 \\
Diospyros lancifolia & 33.33 & 7.46 & 41.66 & 3.63 & 2.62 & 5.86 & 16.95 \\
Lyonia ovalifolia & 26.67 & 5.97 & 26.26 & 2.29 & 2.3 & 5.14 & 13.40 \\
Syzygium cumini & 33.33 & 7.46 & 13.33 & 1.16 & 1.85 & 4.14 & 12.76 \\
Pyrus pashia & 20 & 4.48 & 15 & 1.31 & 1.92 & 4.29 & 10.08 \\
Dalbergia sissoo & 20 & 4.48 & 10 & 0.87 & 1.63 & 3.64 & 8.99 \\
Pinus roxburghii & 13.33 & 2.98 & 21.66 & 1.89 & 1.82 & 4.07 & 8.94 \\
Castanopsis indica & 13.33 & 2.98 & 15 & 1.31 & 1.8 & 4.02 & 8.31 \\
Mangifera indica & 20 & 4.48 & 8.33 & 0.73 & 1.23 & 2.75 & 7.95 \\
Toona ciliata & 13.33 & 2.98 & 10 & 0.87 & 1.56 & 3.49 & 7.34 \\
Alnus nepalensis & 6.66 & 1.49 & 16.66 & 1.45 & 1.82 & 4.07 & 7.01 \\
Rhus javanica & 13.33 & 2.98 & 13.33 & 1.16 & 1.24 & 2.77 & 6.92 \\
Mallotus philippensis & 6.66 & 1.49 & 10 & 0.87 & 1.86 & 4.16 & 6.52 \\
Bauhinia purpurea & 13.33 & 2.98 & 11.66 & 1.02 & 1.06 & 2.37 & 6.37 \\
Woodfordia fruticosa & 13.33 & 2.98 & 11.66 & 1.02 & 0.96 & 2.15 & 6.15 \\
Fraxinus floribunda & 13.33 & 2.98 & 6.66 & 0.58 & 0.68 & 1.52 & 5.08 \\
Bauhinia vahlii & 6.66 & 1.49 & 6.66 & 0.58 & 0.98 & 2.19 & 4.26 \\
Bombax ceiba & 6.66 & 1.49 & 3.33 & 0.29 & 0.8 & 1.79 & 3.57 \\
Ficus benjamina & 6.66 & 1.49 & 1.66 & 0.14 & 0.65 & 1.45 & 3.09 \\
Celtis australis & 6.66 & 1.49 & 1.66 & 0.14 & 0.23 & 0.51 & 2.15 \\
Total & 445.94 & 100 & 1148.52 & 100 & 44.74 & 100 & 300 \\
\hline
\end{tabular}

Table 4. Frequency, relative frequency, density, relative density, basal area, relative basal area and importance value index of plant species in site B of the study area

\begin{tabular}{lccccccc}
\hline Species & $F(\%)$ & RF (\%) & $D\left(\right.$ plants ha $\left.{ }^{-1}\right)$ & RD (\%) & BA (\%) & RBA (\%) & IVI \\
\hline Shorea robusta & 100 & 27.78 & 516 & 62.12 & 19.22 & 40.85 & 130.75 \\
Schima wallichii & 66.66 & 18.52 & 178 & 21.43 & 9.45 & 20.09 & 60.03 \\
Diospyros lancifolia & 46.66 & 12.96 & 41.66 & 5.02 & 4.17 & 8.86 & 26.84 \\
Lyonia ovalifolia & 20 & 5.56 & 36.66 & 4.41 & 3.1 & 6.59 & 16.56 \\
Ficus semicordata & 26.66 & 7.41 & 16.66 & 2.01 & 2.2 & 4.68 & 14.09 \\
Pyrus pashia & 13.33 & 3.70 & 11.66 & 1.40 & 2.8 & 5.95 & 11.06 \\
Terminalia alata & 20 & 5.56 & 8.33 & 1.00 & 1.2 & 2.55 & 9.11 \\
Litsea monopetala & 20 & 5.56 & 3.33 & 0.40 & 0.86 & 1.83 & 7.79 \\
Aesandra butryracea & 13.33 & 3.70 & 3.33 & 0.40 & 1.22 & 2.59 & 6.70 \\
Phyllanthus emblica & 13.33 & 3.70 & 5 & 0.60 & 0.92 & 1.96 & 6.26 \\
Bauhinia vahlii & 6.66 & 1.85 & 6.66 & 0.80 & 0.82 & 1.74 & 4.39 \\
Ficus lacor & 6.66 & 1.85 & 1.66 & 0.20 & 0.84 & 1.79 & 3.84 \\
Fraxinus floribunda & 6.66 & 1.85 & 1.66 & 0.20 & 0.25 & 0.53 & 2.58 \\
Total & 359.95 & 100 & 830.61 & 100 & 47.05 & 100 & 300 \\
\hline
\end{tabular}

\section{Community structure}

Among the plant species recorded in site A, sal had the highest IVI (122.2) and Celtis australis L. had the lowest IVI (2.2; Table 3). The other plant species having high IVI in site A were $S$. wallichii (32), D. lancifolia (17), Lyonia ovalifolia (Wall.) Drude (13.4), Syzygium cumini (L.) Skeels (12.8) and Pyrus pashia Buch.-Ham. ex D. Don (10.1) (Table 3). Similarly, among the plant species recorded in site $\mathrm{B}$, those having the highest and lowest IVI were sal (130.8) and Fraxinus floribunda Wall. (2.6) respectively (Table 4). The other plant species having high IVI in site B were S. wallichii (60.03), D. lancifolia
(26.8), L. ovalifolia (16.6), Ficus semicordata Buch.Ham. ex Sm. (14.1) and P. pashia (11.1) (Table 4).

The total density in site A was 1148.5 plants $\mathrm{ha}^{-1}$, which was higher than the total density in site B (830.6 plants $\mathrm{ha}^{-1}$ ). However, the total basal area in site $\mathrm{A}$ $\left(44.74 \mathrm{~m}^{2} \mathrm{ha}^{-1}\right)$ was similar to that in site B $\left(47.05 \mathrm{~m}^{2} \mathrm{ha}^{-1}\right)$ (Tables 3 and 4).

Dipterocarpaceae had the highest IVI (122.17), followed by Theaceae (32), Fabaceae (19.62) and Ebenaceae (6.95) in site A, while Ulmaceae had the lowest IVI (2.15) in site A (Table 5). Similarly, in site B, Dipterocarpaceae had the highest IVI (130.75), followed by Theaceae (60.03), Ebenaceae (26.84) and Moraceae 
Table 5. Frequency, relative frequency, density, relative density, basal area, relative basal area and importance value index of families of plant species in site A of the study area

\begin{tabular}{lccccccc}
\hline Family & $F(\%)$ & RF $(\%)$ & $D\left(\right.$ plants ha $\left.{ }^{-1}\right)$ & RD $(\%)$ & BA $(\%)$ & RBA $(\%)$ & IVI \\
\hline Dipterocarpaceae & 100 & 22.39 & 804 & 70 & 13.32 & 29.77 & 122.17 \\
Theaceae & 60 & 13.44 & 100 & 8.71 & 4.41 & 9.86 & 32 \\
Fabaceae & 39.33 & 8.95 & 28.32 & 2.47 & 3.67 & 8.2 & 19.62 \\
Ebenaceae & 33.33 & 7.46 & 41.66 & 3.63 & 2.62 & 5.86 & 16.95 \\
Anacardiaceae & 33.33 & 7.46 & 21.66 & 1.89 & 2.47 & 5.52 & 14.87 \\
Ericaceae & 26.67 & 5.97 & 26.26 & 2.29 & 2.3 & 5.14 & 13.4 \\
Myrtaceae & 33.33 & 7.46 & 13.33 & 1.16 & 1.85 & 4.14 & 12.76 \\
Rosaceae & 20 & 4.48 & 15 & 1.31 & 1.92 & 4.29 & 10.08 \\
Pinaceae & 13.33 & 2.98 & 21.66 & 1.89 & 1.82 & 4.07 & 8.94 \\
Fagaceae & 13.33 & 2.98 & 15 & 1.31 & 1.8 & 4.02 & 8.31 \\
Meliaceae & 13.33 & 2.98 & 10 & 0.87 & 1.56 & 3.49 & 7.34 \\
Betulaceae & 6.66 & 1.49 & 16.66 & 1.45 & 1.82 & 4.07 & 7.01 \\
Euphorbiaceae & 6.66 & 1.49 & 10 & 0.87 & 1.86 & 4.16 & 6.52 \\
Lythraceae & 13.33 & 2.98 & 11.66 & 1.02 & 0.96 & 2.15 & 6.15 \\
Oleaceae & 13.33 & 2.98 & 6.66 & 0.58 & 0.68 & 1.52 & 5.08 \\
Bombacaceae & 6.66 & 1.49 & 3.33 & 0.29 & 0.8 & 1.79 & 3.57 \\
Moraceae & 6.66 & 1.49 & 1.66 & 0.14 & 0.65 & 1.45 & 3.09 \\
Ulmaceae & 6.66 & 1.49 & 1.66 & 0.14 & 0.23 & 0.51 & 2.15 \\
Total & 445.94 & 100 & 1148.52 & 100 & 44.74 & 100 & 300 \\
\hline
\end{tabular}

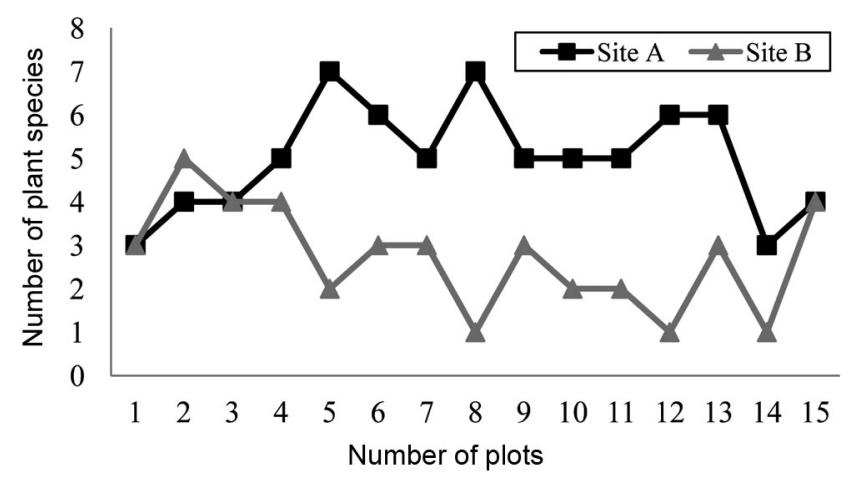

Figure 2. Species-area curve in the two forest sites A and B.

(17.93), while Oleaceae (2.58) had the lowest IVI (Table 6).

\section{Regeneration status of forest}

The total number of seedlings, saplings and trees of all species in the study area was 12,589, 2643 and 1979 individuals $\mathrm{ha}^{-1}$ respectively (Figure $3 \mathrm{a}$ ). Similarly, the total number of seedlings (6853 individuals $\left.\mathrm{ha}^{-1}\right)$, saplings (1481 individuals $\mathrm{ha}^{-1}$ ) and trees (1148 individuals $\mathrm{ha}^{-1}$ ) in site A was higher than the total number of seedlings (5736 individuals $\mathrm{ha}^{-1}$ ), saplings (1162 individuals $\mathrm{ha}^{-1}$ ) and trees (831 individuals $\mathrm{ha}^{-1}$ ) in site B (Figure $3 a$ ). The total number of sal seedlings, saplings and trees in the study area was 8352, 1876 and 1320 individuals $\mathrm{ha}^{-1}$ respectively (Figure $3 \mathrm{~b}$ ). Likewise, the total number of sal seedlings (4384 individuals ha ${ }^{-1}$ ), saplings (1043 individuals $\mathrm{ha}^{-1}$ ) and trees (804 individuals $\mathrm{ha}^{-1}$ ) in site A was higher than the total number of sal seedlings (3968 individuals $\left.\mathrm{ha}^{-1}\right)$, saplings (833 individuals $\left.\mathrm{ha}^{-1}\right)$ and trees $\left(516\right.$ individuals $\mathrm{ha}^{-1}$ ) in site $\mathrm{B}$ (Figure $3 \mathrm{~b}$ ).

The DBH size-class distribution diagram of all the tree species showed an interrupted curve, with the highest peak in DBH size classes $15-20$ and $20-25 \mathrm{~cm}$ for the entire study area, site A and site B; this is due to the greater number of individuals in the DBH size classes 15-20 and 20-25 cm than other size classes (Figure $4 a$ ). The DBH size-class distribution diagram for sal trees was an inverse $J$-shaped curve, except for the study site $\mathrm{B}$, where an almost linear pattern was obtained (Figure $4 b$ ). The inverse $J$-shaped curve is due to the gradual decrease in the number of individuals with increasing DBH class.

\section{Discussion}

The number of species recorded in the present study (27) was found to be lower than that reported from Nep$\mathrm{al}^{36,38,39}$, India ${ }^{4,40-43}$ and Bangladesh ${ }^{27}$. The present study found a higher number of species than that reported in the tropical semi-evergreen forests of Manipur, India ${ }^{44}$ and Siwalik sal forest of central Himalaya ${ }^{19}$. However, species richness in the present study was similar to that reported from dipterocarp forests of Bangladesh ${ }^{45}$, sal forest of western Nepal ${ }^{13}$, dry sal forest of West Bengal, India $^{42}$, tropical sal forest of Nepal ${ }^{17}$ and tropical semievergreen forests of North East, India ${ }^{46}$. The variations in biogeography, habitat, climate, soil, geographical location and disturbance cause great changes in tree species diversity in different locations ${ }^{6,47}$. Therefore, the variation of species richness in the present study compared to 
Table 6. Frequency, relative frequency, density, relative density, basal area, relative basal area and importance value index of families of plant species in site B of the study area

\begin{tabular}{lccccccc}
\hline Family & $F(\%)$ & RF $(\%)$ & $D\left(\right.$ plants ha $\left.^{-1}\right)$ & RD (\%) & BA (\%) & RBA (\%) & IVI \\
\hline Dipterocarpaceae & 100 & 27.78 & 516 & 62.12 & 19.22 & 40.85 & 130.75 \\
Theaceae & 66.66 & 18.52 & 178 & 21.43 & 9.45 & 20.09 & 60.03 \\
Ebenaceae & 46.66 & 12.96 & 41.66 & 5.02 & 4.17 & 8.86 & 26.84 \\
Moraceae & 33.32 & 9.26 & 18.32 & 2.21 & 3.04 & 6.47 & 17.93 \\
Ericaceae & 20 & 5.56 & 36.66 & 4.41 & 3.1 & 6.59 & 16.56 \\
Rosaceae & 13.33 & 3.7 & 11.66 & 1.4 & 2.8 & 5.95 & 11.06 \\
Combretaceae & 20 & 5.56 & 8.33 & 1 & 1.2 & 2.55 & 9.11 \\
Lauraceae & 20 & 5.56 & 3.33 & 0.4 & 0.86 & 1.83 & 7.79 \\
Sapotaceae & 13.33 & 3.7 & 3.33 & 0.4 & 1.22 & 2.59 & 6.7 \\
Euphorbiaceae & 13.33 & 3.7 & 5 & 0.6 & 0.92 & 1.96 & 6.26 \\
Fabaceae & 6.66 & 1.85 & 6.66 & 0.8 & 0.82 & 1.74 & 4.39 \\
Oleaceae & 6.66 & 1.85 & 1.66 & 0.2 & 0.25 & 0.53 & 2.58 \\
Total & 359.95 & 100 & 830.61 & 100 & 47.05 & 100 & 300 \\
\hline
\end{tabular}
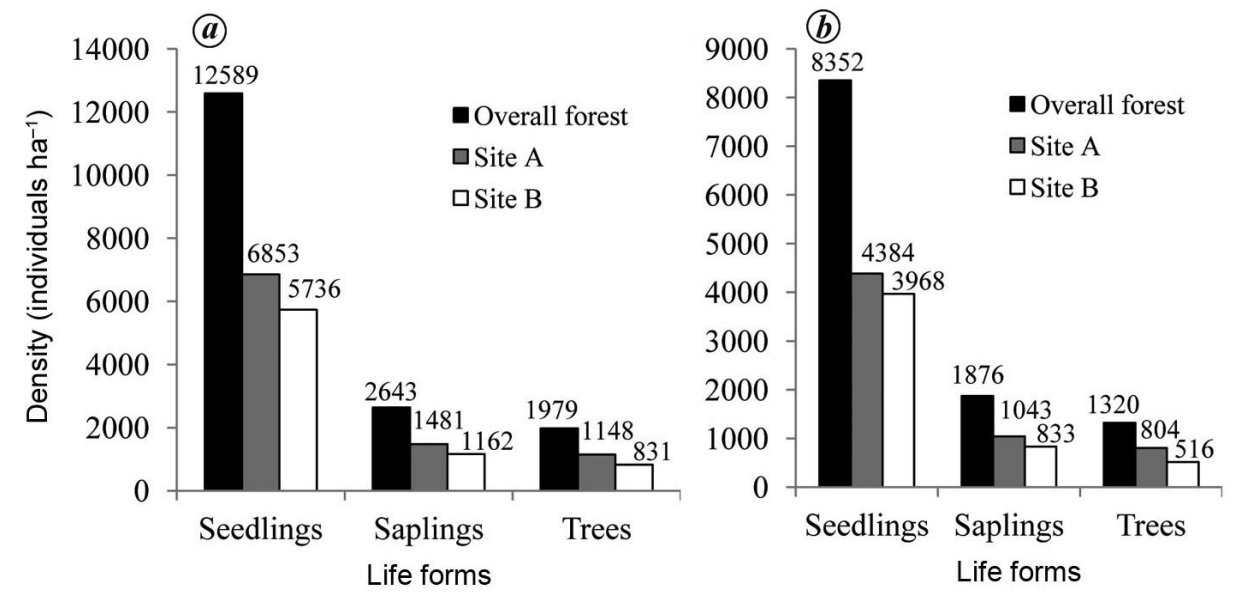

Figure 3. $\boldsymbol{a}$, Total number of seedlings, saplings and trees of all species in the entire study area, site A and site B. $\boldsymbol{b}$, Total number of sal seedlings, saplings and trees in the entire study area, site A and site B.

the studies mentioned above may be due to the differences in the above-mentioned factors between them.

The present study showed a higher number of species diversity in disturbed site, i.e. site A than in relatively undisturbed site, i.e. site B. Further, site A had a higher number of species per plot than site B. Thus, we may infer that disturbance supports species diversity in the sal-dominated forest. For example, disturbances like grazing help in seed dispersal from surrounding habitats and the open area facilitates to establish them. Also, species richness may increase with mild disturbance ${ }^{30}$. Likewise, greater species diversity in the disturbed site may be due to the three-dimensional light-capture mechanisms as the disturbed sites get more light because they have better three-dimensional space-filling canopies $^{48}$. The other reason may be the plantation of species like $P$. roxburghii, $D$. sissoo, $F$. semicordata, etc. after management. The species richness was high in the low disturbed sal forest than the highly disturbed sal forest in $\mathrm{Nepal}^{49}$ and Bangladesh ${ }^{27}$, which supports our results.

Similarity index was used to find similarity and diversity of species in the region. Similarity index showed that both sites were different in terms of species composition and had high beta diversity. Jaccard and Sorenson indices of the old growth and secondary growth forest were different ${ }^{50}$. The 15-year-old forests had Jaccard index $0.19(19 \%)$ and Sorenson index $0.32(32 \%)$, while forests of more than 200 years had Jaccard index 0.30 (30\%) and Sorenson index $0.46(46 \%)$. The sacred groves of Manipur, North East India had Jaccard index $0.35(35 \%)^{5}$, while sal forest of Rupandehi, Nepal had Jaccard index $0.43(43 \%)-0.73 .3(73.3 \%)^{13}$. This shows that the similarity indices of the present study are within the range of previously mentioned studies.

The IVI of any species indicates the dominance of the species in a mixed population ${ }^{4}$. Among the total species encountered, the highly dominant species was sal which was followed by $S$. wallichii and D. lancifolia in both the study sites of the forest, while the remaining species were infrequent and sparsely distributed. Generally, sal is the dominant tree in the forests where it occurs ${ }^{41}$, and the dominance of sal depends on age, available resources, associate species, disturbance regime and successional changes $^{51}$. The dominance of these species may be due to 

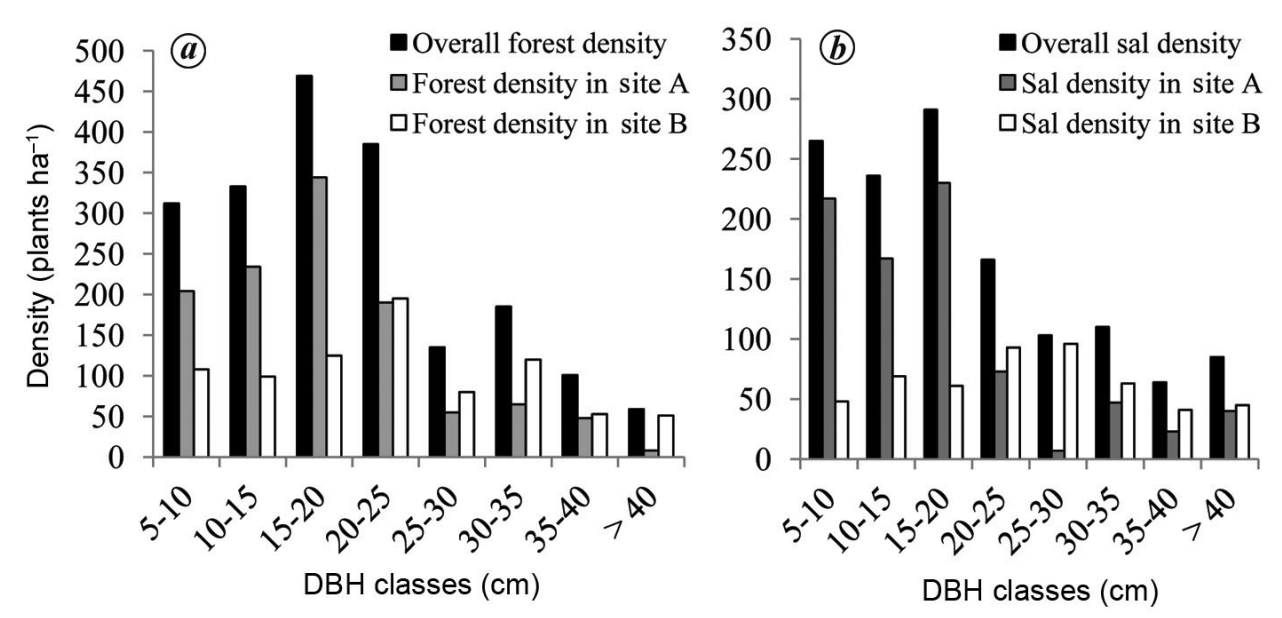

Figure 4. Size-class distribution: $(\boldsymbol{a})$ density of all tree species in the entire study area and two sites and (b) sal density in the entire study area and two study sites.

the excellent dispersal capacities of their seeds, pollen grains, etc. ${ }^{10}$, their good power of regeneration and greater ecological amplitude ${ }^{52}$. The dominance of a species results due to species preference, management activities, overutilization and removal of other species from a mixed forest stand ${ }^{53}$. The dominant species are important from both biodiversity conservation and commercial point of view, while the infrequent and sparsely distributed species need proper protection and conservation. Among the families, Dipterocarpaceae was dominant followed by Theaceae in both the sites of the studied forest. Ulmaceae and Oleaceae were the rarest families in sites A and B respectively, in terms of species composition. The dominance of any family may be due to the excellent dispersal capacity of its seeds, pollen grains, etc. by wind, water, birds, mammals, bats and humans ${ }^{10}$.

The total tree density in the disturbed site prior to management (site A) was higher than the low disturbed site prior to management (site B). Our result diverts from that obtained by a previous study from Bangladesh, where it was found that low disturbed sites have a high density and basal area than the highly disturbed sites ${ }^{27}$. Species composition and degree of disturbance may be the cause for variation in density between the two sites (A and B) of the forests ${ }^{54}$. Variation of tree density may also be affected by natural calamities, anthropogenic activities and soil properties ${ }^{54}$. A basal area of 44.7 and $47.1 \mathrm{~m}^{2}$ $\mathrm{ha}^{-1}$ in sites A and B respectively, of the present studied forest is within the range $\left(19.6-63.9 \mathrm{~m}^{2} \mathrm{ha}^{-1}\right)$ as observed from Nepal, Bangladesh and India ${ }^{4,17,27,38-40,42,43,45}$. Similarly, sites A and B had a density of 1148.5 and 830.6 plants ha ${ }^{-1}$ respectively, which is within the range recorded by previous studies ${ }^{4,41,42,55}$.

Tree distribution across different girth classes revealed how well the growing forest is utilizing functional and structural resources ${ }^{54}$. In this study, interrupted size-class distribution curve having higher tree density in interme- diate diameter classes was obtained for all other species except for sal species in site A and the entire forest. Thus, according to the distribution curve, the present studied forest cannot be considered as a sustainable and viable type of forest. A similar result was obtained in the dipterocarp forests of Bangladesh ${ }^{45}$. The size-class distributions that divert from the inverse $J$-shaped curve indicate human disturbances ${ }^{36}$, such as those observed in the present study. The lower tree density in lower diameter classes and higher diameter classes compared to intermediate diameter class can be due to selective felling of lower girth class plants in the disturbed site, while in the undisturbed stand it can be due to low tree mortality and lower tree removal rate across the intermediate diameter classes. The increase in species number, density and frequency of the herbaceous community due to disturbances causes reduction of tree seedling establishment growth, which ultimately leads to reduction of trees with lower girth class ${ }^{46}$.

The total number of seedlings, saplings and trees of all species and the total number of sal seedlings, saplings and trees were higher in site A than site B of the studied forest. This situation can be correlated with the degree of disturbance prior to management, as site A is relatively disturbed compared to site $\mathrm{B}$. The disturbance intensity in site A may have caused opening of the canopy, which may have facilitated regeneration and growth of understorey seedlings and saplings, as sal is a light-demanding species and complete overhead light is needed in most cases from the earliest stages of its development ${ }^{56}$. However, the lesser number of saplings or seedlings even in the relatively undisturbed forest site could be either due to competition among the intra-species to grow, or due to the dense canopy cover resulting in lack of light for regeneration. The regeneration status of the present studied forest was within the range of various previous studies $^{11,13,17,36}$. Similarly, regeneration status of sal was 
also within the range of previous studies ${ }^{11,13,17,30,36}$. From the regeneration count, we conclude that the forest under study has good regeneration status with a sufficient number of seedlings and saplings to replace the adults after their mortality.

\section{Conclusion and recommendations}

Twenty-seven species belonging to 21 families were recorded in the presently studied CF. The disturbed site (site A) had more number of species than the relatively undisturbed site (site B) of the forest. Sal was the dominant species followed by $S$. wallichii and D. lancifolia, while other species were infrequent and rarely distributed. Dipterocarpaceae was the dominant family in terms of distribution, while Fabaceae and Moraceae were the species-rich families consisting of three species each. The size-class distribution curve shows that the forest as well as both the studied sites cannot be considered sustainable and viable as the curve diverts from the inverse $J$-shaped. Contrary to this, regeneration count depicts that the forest as well as both the studied sites have good regeneration status with a sufficient number of seedlings and saplings to replace the adults after their mortality, which is considered to be viable population regeneration pattern. However, the density of seedlings, saplings and trees was found higher in the disturbed site than the relatively undisturbed site of the forest. Thus, the study indicates that there are considerable differences between the disturbed and relatively undisturbed site prior to management of the sal-dominated CF in terms of diversity, composition, stand structure and regeneration pattern. We conclude that such disturbance supports the number of species and regeneration of plants in the sal-dominated forest.

The dominant species are important in terms of biodiversity conservation and commercial point of view, while the infrequent and sparsely distributed species need special priority for proper protection, conservation and regeneration. This study may serve as a baseline for assessing the state of species richness, diversity and regeneration status at different disturbance intensities in Nepal. Moreover, tree species density, distribution, population structure and regeneration analysed in this study may be useful to conservation researchers and scientists, and also to forest managers for effective forest conservation. The conservation and protection of the presently studied forest are crucial not only for conservation of its existing resources and biodiversity, but also for the restoration of degraded resources and meeting the basic needs of the local population.

1. Singh, S., Malic, Z. A. and Sharma, C. M., Tree species richness, diversity, and regeneration status in different oak (Quercus spp.) dominated forests of Garhwal Himalaya, India. J. Asia-Pac. Biodivers., 2016, 9, 293-300.

2. Malik, Z. A. and Bhatt, A. B., Phytosociological analysis of woody species in Kedarnath Wildlife Sanctuary and its adjoining areas in Western Himalaya, India. J. For. Environ. Sci., 2015, 31, 149-163.

3. Mishra, A. K., Behera, S. K., Singh, K., Mishra, R. M., Chaudhary, L. B. and Singh, B., Influence of abiotic factors on community structure of understory vegetation in moist deciduous forests of north India. For. Sci. Pract., 2013, 15, 261-273.

4. Sarkar, M. and Devi, A., Assessment of diversity, population structure and regeneration status of tree species in Hollongapar Gibbon Wildlife Sanctuary, Assam, Northeast India. Trop. Plant Res., 2014, 1, 26-36.

5. Khumbongmayum, A. D., Khan, M. L. and Tripathi, R. S., Biodiversity conservation in sacred groves of Manipur, northeast India: population structure and regeneration status of woody species. Biodivers. Conserv., 2006, 15, 2439-2456.

6. Ram, J., Kumar, A. and Bhatt, J., Plant diversity in six forest types of Uttaranchal, Central Himalaya, India. Curr. Sci., 2004, 86, 975-978.

7. Bose, A. K., Weiskittel, A., Wagner, R. G. and Kuehne, C., Assessing the factors influencing natural regeneration patterns in the diverse, multi-cohort, and managed forests of Maine, USA. J. Veg. Sci., 2016, 27, 1140-1150.

8. Gilliam, F. S., The ecological significance of the herbaceous layer in temperate forest ecosystems. BioScience, 2007, 57, 845-858.

9. Bharali, S., Paul, A., Khan, M. L. and Singha, L. B., Impact of altitude on population structure and regeneration status of two Rhododendron species in a temperate broad leaved forest of Arunachal Pradesh, India. Int. J. Ecosyst., 2012, 2, 19-27.

10. Rahman, M. H., Khan, A. S. A., Roy, B. and Fardusi, M. J., Assessment of natural regeneration status and diversity of tree species in the biodiversity conservation areas of Northeastern Bangladesh. J. For. Res., 2011, 22, 551-559.

11. Napit, R., Species diversity, forest community structure and regeneration in Banke National Park, Nepal. Nepal J. Sci. Technol., 2015, 16, 17-30.

12. Zhang, Y., Zheng, Z. H. and Zhang, Z. X., Community structure and regeneration types of Betula dahurica forest in Badaling Forest Center of Beijing. For. Stud. China, 2007, 9, 152-156.

13. Awasthi, A., Bhandari, S. K. and Khanal, Y., Does scientific forest management promote plant species diversity and regeneration in sal (Shorea robusta) forest? A case study from Lumbini collaborative forest, Rupandehi, Nepal. Banko Janakari, 2015, 25, 20-29.

14. Chauhan, P. S., Negi, J. D. S., Singh, L. and Manhas, R. K., Regeneration status of sal forests of Doon valley. Ann. For., 2008, 16, $178-182$.

15. Tripathi, R. S. and Khan, M. L., Regeneration dynamics of natural forests - a review. Proc. Indian Natl. Sci. Acad., 2007, 73, 167195.

16. Pokhriyal, P., Uniyal, P., Chauhan, D. S. and Todaria, N. P., Regeneration status of tree species in forest of Phakot and Pathri Rao watersheds in Garhwal Himalaya. Curr. Sci., 2010, 98, 171174.

17. Basyal, S., Lekhak, H. D. and Devkota, A., Regeneration of Shorea robusta Gaertn. in tropical forest of Palpa district, Central Nepal. Sci. World, 2011, 9, 53-56.

18. Borja, M. E. L., Climate change and forest natural regeneration in Mediterranean mountain areas. For. Res., 2014, 3, e108.

19. Singh, J. S. and Singh, S. P., Forests of Himalaya: Structure, Functioning, and Impact of Man, Gyanodaya Prakashan, Dehradun, 1992.

20. Block, J. and Treter, U., The limiting factors at the upper and lower forest limits in the mountain-woodland steppe of northwest Mongolia. In Proceedings of the International Conference on Tree Rings and People (eds Kaennel, D. M. and Baker, O. U.), Davos, Switzerland, 2001.

21. Felsmann, K., Baudis, M., Kayler, Z. E., Puhlmann, H., Ulrich, A. and Gessler, A., Responses of the structure and function of the 
understory plant communities to precipitation reduction across forest ecosystems in Germany. Ann. For. Sci., 2018, 75, 3.

22. Duan, R. Y., Wang, X. A., Tu, Y. B., Huang, M. Y., Wang, C., Zhu, Z. H. and Guo, H., Recruitment pattern of tree populations along an altitudinal gradient: Larix chinensis Beissn in Qinling mountains (China). Pol. J. Ecol., 2009, 57, 451-459.

23. Acharya, K. P., Twenty-four years of community forestry in Nepal. Int. For. Rev., 2002, 4, 149-156.

24. DFSC, Community forestry database, Department of Forestry and Soil Conservation, Kathmandu, Nepal, 2018 (accessed on 15 December 2018).

25. Ojha, H., Persha, L. and Chhatre, A., Community forestry in Nepal: a policy innovation for local livelihoods and food security. International Food Policy Research Institute, Washington DC, USA, 2009.

26. Chaubey, O. P. and Sharma, A., Population structure and regeneration potential of sal (Shorea robusta Gaertn. f.) and its associates in sal bearing forests of Satpura Tiger Reserve. Int. J. BioSci. Bio-Technol., 2013, 5, 63-70.

27. Rahman, M. M., Nishat, A. and Vacik, H., Anthropogenic disturbances and plant diversity of the Madhupur sal forests (Shorea robusta C. F. Gaertn.) of Bangladesh. Int. J. Biodivers. Sci. Manage., 2009, 5, 162-173.

28. Khanna, L. S. and Chaturvedi, A. N., Forest Mensuration, International Book Distributors, Dehradun, 1985.

29. Rawat, D. S., Dash, S. S., Sinha, B. K., Kumar, V., Banerjee, A. and Singh, P., Community structure and regeneration status of tree species in Eastern Himalaya: a case study from Neora Valley National Park, West Bengal, India. Taiwania, 2018, 63, 16-24.

30. Acharya, R. and Shrestha, B. B., Vegetation structure, natural regeneration and management of Parroha community forest in Rupandehi district, Nepal. Sci. World, 2011, 9, 70-81.

31. Maren, I. E., Karki, S., Prajapati, C., Yadav, R. K. and Shrestha, B. B., Facing north or south: does slope aspect impact forest stand characteristics and soil properties in a semiarid trans-Himalayan valley? J. Arid Environ., 2015, 121, 112-123.

32. Malla, S. B., Rajbhandary, S. B., Shrestha, T. B., Adhikari, P. M., Adhikari, S. R. and Shakya, P. R., Flora of Kathmandu Valley, Bulletin of Medicinal Plants of Nepal No. 11, Department of Medicinal Plants, Kathmandu, Nepal, 1986.

33. Polunin, O. and Stainton, A., Flowers of the Himalaya (4th Impression), Oxford University Press, New Delhi, 2000.

34. Press, J. R., Shrestha, K. K. and Sutton, D. A., Annotated Checklist of Flowering Plants of Nepal, The Natural History Museum, London, UK, 2000.

35. Yadav, U. K. R., Jha, P. K., Behan, M. J. and Zobel, D. B., A Practical Manual for Ecology, Ratna Book Distributors, Kathmandu, Nepal, 1987.

36. Timilsina, N., Rossn, M. S. and Heinen, J. T., A community analysis of sal (Shorea robusta) forest in the western Terai of Nepal. For. Ecol. Manage., 2007, 241, 223-234.

37. Chao, A., Chazdon, R. L., Colwell, R. K. and Shen, T. J., A new statistical approach for assessing similarity of species composition with incidence and abundance data. Ecol. Lett., 2005, 8, 148-159.

38. Bhatta, S. P., Sharma, K. P. and Balami, S., Variation in carbon storage among tree species in the planted forest of Kathmandu, Central Nepal. Curr. Sci., 2018, 115, 274-282.

39. Webb, E. L. and Sah, R. N., Structure and diversity of natural and managed sal (Shorea robusta Gaertn. f.) forest in the Terai of Nepal. For. Ecol. Manage., 2003, 176, 337-353.

40. Manna, S. S. and Mishra, S. P., Diversity, population structure, and regeneration of tree species in Lalgarh forest range of West Bengal, India. Int. J. Bot. Stud., 2017, 2, 191-195.
41. Tripathi, A. K. and Shankar, U., Patterns of species dominance, diversity and dispersion in Khasi hill sal forest ecosystem in northeast India. For. Ecosyst., 2014, 1, 1-20.

42. Kushwaha, S. P. S. and Nandy, S., Species diversity and community structure in sal (Shorea robusta) forests of two different rainfall regimes in West Bengal, India. Biodivers. Conserv., 2012, 21, $1215-1228$.

43. Pandey, S. K. and Shukla, R. P., Plant diversity in managed sal (Shorea robusta Gaertn.) forests of Gorakhpur, India: species composition, regeneration and conservation. Biodivers. Conserv., 2003, 12, 2295-2319.

44. Devi, L. S. and Yadava, P. S., Floristic diversity assessment and vegetation analysis of tropical semievergreen forest of Manipur, north east India. Trop. Ecol., 2006, 47, 89-98.

45. Das, S. C., Alam, M. S. and Hossain, M. A., Diversity and structural composition of species in dipterocarp forests. A study from Fasia Khali Wildlife Sanctuary, Bangladesh. J. For. Res., 2017; doi.10.1007/s11676-017-0548-7.

46. Lalfakawma, Sahoo, U. K., Roy, S., Vanlalhriatpuia, K. and Vanalalhluna, P. C., Community composition and tree population structure in undisturbed and disturbed tropical semi evergreen forest stands of North-East India. Appl. Ecol. Environ. Res., 2009, 7, 303-318.

47. Padalia, H., Chauhan, N., Porwal, M. C. and Roy, P. S., Phytosociological observations on tree species diversity of Andaman Islands, India. Curr. Sci., 2004, 87, 799-806.

48. Naeem, S., Thompson, L. J., Lawler, S. P., Lawton, J. H. and Woodfin, R. M., Declining biodiversity can alter the performance of ecosystems. Nature, 1994, 368, 734-737.

49. Sapkota, I. P., Tigabu, M. and Oden, P. C., Change in tree species diversity and dominance across a disturbance gradient in Nepalese sal (Shorea robusta Gaertn. f.) forests. J. For. Res., 2010, 21, 25-32.

50. Anne, C., Robin, C., Robert, C. and Tsung-Jen, S., Abundancebased similarity indices and their estimation when these are unseen species in samples. Biometrics, 2006, 62, 361-371.

51. Mandal, G. and Joshi, S. P., Quantitative vegetation dynamics and invasion success of Lantana camara from the tropical forests of Doon valley. Int. J. Conserv. Sci., 2014, 5, 11-526.

52. Shameem, S. A. and Kangroo, I. N., Comparative assessment of edaphic features and phytodiversity in lower Dachigam National Park, Kashmir Himalaya, India. Afr. J. Environ. Sci. Technol., $2011, \mathbf{5}, 972-984$.

53. Shrestha, U. B., Shrestha, B. B. and Shrestha, S., Biodiversity conservation in community forests of Nepal: rhetoric and reality. Int. J. Biodivers. Conserv., 2010, 2, 98-104.

54. Naidu, M. T. and Kumar, O. A., Tree diversity, stand structure, and community composition of tropical forests in Eastern Ghats of Andhra Pradesh, India. J. Asia-Pac. Biodivers., 2016, 9, 328-334.

55. Deka, J., Tripathi, O. P. and Khan, M. L., High dominance of Shorea robusta Gaertn. in alluvial plain Kamrup sal forest of Assam, N. E. India. Int. J. Ecosyst., 2012, 2, 67-73.

56. Kayastha, B. P., Silvics of the Trees of Nepal, Community Forestry Development Project, Kathmandu, Nepal, 1985.

ACKNOWLEDGEMENTS. We thank the authorities of the CFUGs for permission to work in the $\mathrm{CF}$ and for providing the necessary information. We also thank the anonymous reviewers for providing insightful comments which helped improve the manuscript.

Received 21 December 2018; revised accepted 14 February 2020

doi: $10.18520 / \mathrm{cs} / \mathrm{v} 119 / \mathrm{i} 1 / 83-92$ 